Accepted refereed manuscript of:

Seles BMPR, Jabbour ABSdL, Jabbour CJC \& Dangelico RM (2016) The Green Bullwhip Effect, the Diffusion of Green Supply Chain Practices, and Institutional Pressures: Evidence from the Automotive

Sector, International Journal of Production Economics, 182, pp. 342-355.

DOI: $\underline{\text { 10.1016/j.ijpe.2016.08.033 }}$

(C) 2016, Elsevier. Licensed under the Creative Commons AttributionNonCommercial-NoDerivatives 4.0 International

http://creativecommons.org/licenses/by-nc-nd/4.0/ 


\title{
The Green Bullwhip Effect, the Diffusion of Green Supply Chain Practices, and Institutional Pressures: Evidence from the Automotive Sector
}

\author{
Bruno Michel Roman Pais Seles a, Ana Beatriz Lopes de Sousa Jabbour ${ }^{\mathrm{c}}$, \\ Charbel José Chiappetta Jabbour (Corresponding Author) ${ }^{d} \&$ Rosa Maria \\ Dangelico ${ }^{\mathrm{b}}$, \\ ${ }^{a}$ Department of Production Engineering, São Paulo State University, Bauru, Brazil \\ ${ }^{b}$ Department of Computer, Control and Management Engineering, Sapienza University \\ of Rome, Rome, Italy \\ c DMEM, University of Strathclyde, Faculty of Engineering, Scotland, UK \\ $d$ Centre for Advanced Management Education, University of Stirling, Scotland, UK
}

Bruno Michel Roman Pais Seles, Ph.D. Student, UNESP-Univ Estadual Paulista (Sao Paulo State Univ), School of Engineering-Bauru. E-mail: bruno_seles@yahoo.com.br.

Ana Beatriz Lopes de Sousa Jabbour, Ph.D., Assistant Professor of Sustainability and Production Engineering at UNESP-Univ Estadual Paulista (Sao Paulo State Univ), School of Engineering-Bauru. Av. Eng. Luiz Edmundo Carrijo Coube, 14-01, Vargem Limpa, Bauru-SP, Brazil, ZipCode: 17033360. Phone/Fax: +0551433036122 E-mail: ablsjabbour@gmail.com.

Charbel José Chiappetta Jabbour, Ph.D., Associate Professor of Sustainability and Production Engineering at UNESP-Univ Estadual Paulista (Sao Paulo State Univ), School of Engineering-Bauru. Av. Eng. Luiz Edmundo Carrijo Coube, 14-01, Vargem Limpa, Bauru-SP, Brazil, ZipCode: 17033360. Phone/Fax: +0551433036122 E-mail: prof.charbel@gmail.com. 
Rosa Maria Dangelico, PhD., Associate Professor at Sapienza University of Rome, Department of Computer, Control and Management Engineering, Rome, Italy. Email: dangelico@dis.uniroma1.it.

The Green Bullwhip Effect, the Diffusion of Green Supply Chain Practices, and Institutional Pressures: Evidence from the Automotive Sector

\section{Highlights}

- This is the first work dedicated to understand the green bullwhip effect in a context of GSCM in Brazil

- An automotive supply chain was analyzed

- We provide details about how institutional environment exercises on generating the green bullwhip effect in the supply chain

- A framework with research propositions is presented 


\title{
The Green Bullwhip Effect, the Diffusion of Green Supply Chain Practices, and Institutional Pressures: Evidence from the Automotive Sector
}

\begin{abstract}
This paper aims to understand and analyze how different institutional pressures created by stakeholders tend to promote the green bullwhip effect and the consequent adoption of green supply chain management (GSCM) practices across a supply chain. It examines GSCM practices adopted in the supply chain as a result of pressure from primary stakeholders, and how they exert environmental pressures. A case study methodology has been adopted to study a focal company (an automotive battery company located in Brazil) and its stakeholders, including customers, its supplier, and the government. The results, synthesized through eight propositions, highlight the effect that the institutional environment exercises on generating the green bullwhip effect in the supply chain.
\end{abstract}

Keywords: green bullwhip effect; green supply chain management; sustainable operations; institutional pressures; stakeholders; automotive sector.

\section{Introduction}

In a search for sustainable production and consumption (Dubey et al., 2016; Wang and Hazen, 2015), green supply chain management (GSCM) has been greatly explored in the literature. Some recent studies on GSCM have explored the direct and indirect relationships between GSCM practices motivated by customers and by environmental and financial performance (Laari et al. 2016); others have identified critical factors related to GSCM (Wu and Chang 2015); have discussed the introduction (Jabbour, 2015) and diffusion (Hazen, Cegielski, and Hanna, 2011) of GSCM in organizations; have proposed new models for improving and selecting suppliers in GSCM (Liou et al. 2016); have proposed methodologies for managing investments in developing green suppliers (Bai, Dhavale, and Sarkis 2016); have affirmed that organizations that adopt environmental management systems more frequently implement GSCM practices (Darnall, Jolley and Handfield, 2008); and have developed systematic (Wong, Wong, and Boon-Itt 2015) and bibliometric reviews (Fahimnia, Sarkis, and Davarzani 2015) on the general topic of GSCM. 
Several studies use stakeholder theory or institutional theory to analyze GSCM (Sarkis, Zhu, and Lai 2011). For example, it is known that stakeholders exercise great environmental pressure and influence the adoption of GSCM practices (Björklund 2011; Mohanty and Prakash 2014; Chien and Shih 2007; Lee 2008) and that the most important stakeholders when it comes to adopting GSCM practices are customers (Mohanty and Prakash 2014; Chien and Shih 2007; Lee 2008). It is also known that specific institutional pressures can motivate companies to adopt specific GSCM practices (Hoejmose, Grosvold, and Millington 2014; Zhu, Sarkis, and Lai 2013; Prajogo, Tang, and Lai 2012). However, according to Zhu, Geng, and Sarkis (2016), it is still unclear how different institutional pressures are related to the adoption of various environmental management practices, which includes GSCM.

Therefore, it is important to understand the circumstances regarding environmental pressure from stakeholders in the focal company in order to understand GSCM (Betts, Wiengarten, and Tadisina, 2015; Meixell and Luoma, 2015) and its enlargement along a supply chain (Laari et al. 2016). This may drive the adoption of GSCM practices, especially in tiers located downstream (Lee et al., 2014). In other words, it is important to understand the potential impacts of institutional pressure on the diffusion of adoption of GSCM practices in supply chains.

Moreover, this article contributes to the GSCM research field by:

- Uncovering evidence, within the same study, of how different stakeholders exert different types of institutional pressure that influences the adoption of GSCM practices. In general, articles have analyzed these two aspects separately, but more studies should focus on investigating whether companies make changes as a result of pressure (Meixell and Luoma, 2015);

- Analyzing institutional pressure from the viewpoint of the parties that create such pressure (Kauppi, 2013);

- Discussing the effects of the enlargement of environmental pressures along a supply chain in order to understand whether or not environmental pressures increase upstream supply chain (Lee et al., 2014). The traditional literature on the supply chain frequently discusses the bullwhip effect, which is related to inaccurate demand forecasts with consequences for increasing inventories upstream in the supply chain. The environmental management literature has identified a parallel between the idea of the amplification of demand from the traditional bullwhip effect and the increase of environmental pressures in the 
upstream supply chain. This article proposes to analyze this parallel further in order to shed light on the spread of GSCM practices across supply chains.

Additionally, there is also the need for more evidence as to whether different environmental pressures have different effects on companies that aim to develop environmental sustainability in their relationship with their suppliers (Sancha, Longoni, and Giménez, 2015).

Therefore, the research question of this article is: how do different institutional pressures exerted by different stakeholders tend to promote the green bullwhip effect through the adoption of GSCM practices in the context of a supply chain located in Brazil?

This paper thus aims to understand and analyze how different institutional pressures created by different stakeholders tend to promote the green bullwhip effect and the consequent adoption of GSCM practices across a supply chain. A case study methodology (Yin, 2010) was used to analyze the relationship between a focal company in the automotive battery supply chain in Brazil, and its primary stakeholders. Few studies have examined stakeholders' pressure in sustainable supply chain management and relative subjects in South America (Meixell and Luoma, 2015) or emerging economies (Khor et al., 2016); and there is a need to understand the differences in dynamics of environmental issues in different countries (Laari et al., 2016; Lee et al., 2014). Consequently, Brazilians companies were selected for this study because Brazil is the leader in the production of motor vehicles (OICA, 2015) and is also the leader in the production and use of lead (ILA, 2016) in South America. Additionally, this country has particular characteristics regarding the institutional environment of the automotive battery sector, which is relevant, according to Silvestre (2015), for analyzing the role of a focal company in terms of leading supply chains toward more sustainable business practices in developing and emerging economies. Data were analyzed using an approach founded on theory, as presented by Glaser and Strauss (2009). More specifically, institutional and stakeholder's theories were used, as these underscore the importance of the position of organizations in the supply chain. Stakeholder theory was used to understand the relationship between these organizations, centering on a focal company in the supply chain, while institutional theory was used in the analysis of the environmental context in which these organizations operate, including institutional pressures. 
The paper is structured as follows. In the next section, the theoretical background is presented. Then, the methodology and data collection details are provided. After that, the results are reported and discussed. Finally, the conclusions of the study, the study's limitations, and recommended future research directions are given.

\section{Theoretical background}

\subsection{Stakeholders and green supply chain management}

Aligned to the definition of supply chain management (Ketchen and Hult, 2007), GSCM is defined as the integration of environmental concerns within the interorganizational practices of supply chain management (Sarkis, Zhu, and Lai, 2011). GSCM is evidenced by the adoption of practices such as internal environmental management, green purchasing, cooperation with customers, investment recovery, ecodesign, and reverse logistics (Sarkis, Zhu, and Lai, 2011; Srivastava 2007, 2008; Zhu, Sarkis, and Lai, 2008a).

The importance of stakeholder theory was recognized in academia and by managers after the publication of "Strategic Management: A Stakeholder Approach" by Freeman (1984). Freeman (1984) defines stakeholders as any group or individual that affects or is affected by the achieving of a company's objectives. Stakeholders include suppliers, collaborators, environmentalists, governments, community, owners, consumer defenders, consumers, and competitors.

Several attempts have been made in the literature to classify stakeholders. The most common distinction is between primary and secondary stakeholders (Clarkson, 1995). Primary stakeholders are those whose participation and support is required if an organization is to survive. These include consumers, suppliers, and regulators. Secondary stakeholders can affect and be affected by the organization, but they have no direct transaction with it, which is why they are not essential for it to survive (Clarkson, 1995). They include media and nongovernmental organizations.

Stakeholders exert great influence on the adoption of GSCM practices, but the type of influence and stakeholder that exert it vary (Meixell and Luoma, 2015). This variation may occur according to the type of industry - i.e., static or dynamic (Betts, Wiengarten, and Tadisina, 2015) - the type of supply chain, the size of the organization, the level of internationalization, the position of an organization in the supply chain, the industrial sector, and the location of the organization (González-Benito and González- 
Benito, 2006a, 2010; Hoejmose, Brammer, and Millington, 2012; Zhu, Sarkis, and Lai, 2008b). The mechanisms used by stakeholders to exert environmental pressures on organizations also vary; the most common include: audits, regulations, demand for green products, competition, contracts with specific clauses, and embargo (Björklund, 2011; Chien and Shih, 2007; Lee 2008; Mohanty and Prakash, 2014). As a result, organizations tend to respond to pressure exerted by stakeholders through training and cooperation with them and by the adoption of environmental practices (González-Benito and González-Benito, 2006b; Sarkis, Gonzalez-Torre, and Adenso-Diaz, 2010).

In the literature, it is possible to identify four types of stakeholders that exert great environmental pressure: competitors, the community, government, and customers.

Competitors tend to motivate organizations indirectly to treat environmental issues strategically in order to achieve an environmental advantage (Mohanty and Prakash, 2014).

Communities play an important role for organizations to adopt GSCM practices, because they demand social and environmental responsibility from companies in their actions (González-Benito and González-Benito 2006a, 2010; Chien and Shih, 2007) and thus, they influence the adoption of GSCM practices (Chien and Shih, 2007; Mohanty and Prakash, 2014).

Governments have the legal authority to demand environmental fitness from organizations (Björklund, 2011; Mohanty and Prakash, 2014; Chien and Shih, 2007; Lee, 2008). However, its influence is not completely understood in the literature, because, in different cases, the government has been seen to influence the adoption of sustainable practices directly or indirectly (Meixell and Luoma, 2015). It may influence the adoption of GSCM practices through specific legislation for given sectors (Chien and Shih, 2007; Björklund, 2011). However, it may stand out in its role as facilitator and disseminator of environmental management practices in supply chains, especially for micro, small-, and medium-sized, enterprises (Lee, 2008).

Customers can be considered as exerting the strongest environmental pressure on organizations. They are the principal demand perception channel for "greener" products or services (Lee, 2008). They influence the adoption of specific GSCM practices (Björklund, 2011), and the direct involvement of customers in supplier practices may drive them to participate more intensely in GSCM initiatives (Lee, 2008). Besides that, foreign customers, especially in developing countries, may exercise great environmental pressure (Chien and Shih, 2007; Mohanty and Prakash, 2014). 
Furthermore, being closer to customers in the supply chain means receiving more intense environmental pressure (González-Benito and González-Benito, 2006a, 2010; Hoejmose, Brammer, and Millington, 2012).

Most of the articles that have addressed stakeholder theory and GSCM have pointed out that pressures from stakeholders affect the adoption of GSCM practices. For example, recently, Chavez et al. (2016) found that customer pressure significantly affects the adoption of customer-centric GSCM; and Dai, Montabor, and Cantor (2015) have highlighted that rival pressure and stakeholder pressure influence GSCM implementation. However, more studies should focus on whether companies make changes as a result of pressure (Meixell and Luoma, 2015) and the potential impact on tiers of supply chains.

\subsection{Institutional environment and green supply chain management}

Organizations operate in environments in which they relate to various other organizations: their stakeholders (DiMaggio and Powell, 1983). These environments are called institutional environments. Institutionalization occurs every time there is reciprocal typification of habitual actions by certain players (Berger and Luckmann, 1967). These actions, that are exerted by relevant institutes, such as social networks, and powerful organizations (Cai, Jun, and Yang, 2010), which may also be understood as social processes, obligations, or realities, assume the status of a rule in relation to social action and thought in an institutional environment (Meyer and Rowan, 1977).

In this context, organizations become similar to other organizations in their institutional environment because these habitual actions are shared, disseminated, stimulated, or copied through three isomorphic processes of change: coercive, mimetic, and normative (DiMaggio and Powell, 1983).

Factors external to organizations, which are present in their institutional environment, such as concern for the environment, influence organizational decisions involving the adoption of management practices or technological innovations (Meyer and Rowan, 1977), such as GSCM.

The relationship between GSCM and institutional theory has been explored in the literature. Sarkis, Zhu, and Lai (2011) conducted a literature review on the relationship between GSCM and various organizational theories, including institutional theory. The authors gathered the results of various studies, including the highlighted ones. Kilbourne, Beckmann, and Thelen (2002), Ball and Craig (2010), and Aerts, 
Cormier, and Magnan (2006) are a few examples. Kilbourne, Beckmann, and Thelen (2002) showed that coercive pressure, especially on the part of the government, is an important motivator for the adoption of environmental management practices. Ball and Craig (2010) found that the normative pressure generated by consumers has motivated the adoption of GSCM practices. Aerts, Cormier, and Magnan (2006) found that imitation plays an important role for companies in developed countries when it comes to adopting GSCM practices.

According to some recent studies, it is known that there are different standards for adopting GSCM depending on the type of institutional pressure exerted (Carbone and Moatti, 2011). It is known that specific institutional pressures can motivate manufacturing companies to adopt specific GSCM practices (Hoejmose, Grosvold, and Millington, 2014; Zhu, Sarkis, and Lai, 2013; Prajogo, Tang, and Lai, 2012), such as internal practices (Zhu, Sarkis, and Lai, 2013; Prajogo, Tang, and Lai, 2012) and cooperative practices (Hoejmose, Grosvold, and Millington, 2014); it is also known that mimetic pressures have a positive effect on the development of more sustainable suppliers (Sancha, Longoni, and Giménez, 2015) and that coercive pressures positively relate to internal environmental management practices, whereas less coercive pressures positively relate to external GSCM practices (Zhu, Geng, and Sarkis, 2016). Furthermore, institutional pressures have a moderating effect on a management's relations with suppliers and on environmental performance (Dubey, Gunasekaran, and Ali, 2015). They also influence top management's actions in terms of the adoption of GSCM practices, such as reverse logistics (Ye et al., 2013), and proactive environmental practices, especially in international markets (Zhu, Sarkis, and Lai, 2011; Zhu, Cordeiro, and Sarkis, 2012).

In general, studies have analyzed the influence of institutional pressures created by a type of stakeholder (e.g., top management or customers) on the adoption of sustainable practices such as GSCM (Dubey et al., 2016; Chavez et al., 2016; Dai et al., 2015). However, stakeholders and their consequent environmental pressures could influence a focal company differently. Therefore, it is relevant to integrate these two perspectives simultaneously in order to understand the potential impacts of institutional pressures on the spread of GSCM practices in the supply chain.

\subsection{Diffusion of GSCM and the green bullwhip effect}

Institutional theory and stakeholder theory can help to explain the diffusion of 
environmental pressure in supply chains and, consequently, the adoption of GSCM practices. Articles by researchers such as González, Sarkis, and Adenso-Diáz (2008) have suggested that certified environmental management system companies tend to pressure their suppliers into adopting environmental practices, which implies a diffusion of environmental concerns upstream in the supply chain. This could be related to coercive pressure. However, it is necessary to study this issue further for a more detailed understanding of the enlargement of environmental concerns. Therefore, it is important to consider the implications of an organization's position in the supply chain, together with these two theories.

The position in the supply chain helps to explain how environmental pressures are propagated and the type of environmental practices that are being adopted as a result across the supply chain (Lo, 2013). According to Lo (2013), downstream companies adopt more practices such as eco-design, green purchasing, and internal environmental management, whereas those at the center of a supply chain generally adopt green manufacturing and logistics practices. When analyzing the propagation of environmental pressure from the perspective of the company's position in the supply chain, one perceives the existence of the green bullwhip effect phenomenon, which has mainly been evidenced by Lee et al. (2014). It has also been supported by Laari et al. (2016), while Asgary and Li (2014) have considered the issue in terms of unethical operations and the damage to companies' reputations.

The traditional bullwhip effect is characterized by the distortion of information coming from end customers in the supply chain. This results in the generation of uncertainties regarding demand in upstream tiers, which reflects directly on inventories and on product decisions (Lee, Padmanabhan, and Whang, 1997). The green bullwhip effect is similar to this effect. The term is used to describe a dynamic set of responses to environmental issues in supply chains, and the result of this effect is that the environmental requirements of customers become more rigorous and restrictive upstream in the supply chain (Lee et al., 2014). Some characteristics of the phenomenon are: the rigor of demands on products and materials based on environmental characteristics tend to increase as they move upstream in the supply chain; the deadline for meeting the requirements based on environmental issues tends to get shorter at each successive upstream level in the supply chain; and the responses to the green bullwhip effect in the supply chain may vary in accordance with the characteristics of the relationships between customers and suppliers (Lee et al., 2014). 
The green bullwhip effect is an event motivated by changes in environmental requirements such as new regulations, and the industry needs to respond to environmental incidents, practicing urgency when it comes to meeting new environmental pressures from customers (Lee et al., 2014) and moving them upstream in the chain (Laari et al., 2016). These changes can create risks and uncertainties, complicating the response to them and managerial planning in a chain (Lee et al., 2014).

\section{Design of the Research}

This research was based on a case study method with the purpose of theory generation (Ketokivi and Choi, 2014). Ketokivi and Choi (2014) explained that a case study as theory generation has an inductive approach and it is based on comparison and contrast between the previously established theory and the emergent results from a case study. Context and data are important to refine the theory. Theoretical propositions are created as a result of the comparative analyses.

The context of this research can provide more understandable comprehension regarding the enlargement of environmental concerns across a supply chain, due to some particular characteristics of the sector analyzed, which is explained in section 3.1. Therefore, previous assumptions from the literature are compared with results from the case study in order to explain the theory (Ketokivi and Choi, 2014) and create propositions, which could be tested in future research. Section 4 of the article develops the comparative analyses and creation of propositions. Table 1 presents the constructs and variables of the theoretical research which guided the process of comparison between previous literature and insights from the case study.

A single case, embracing four firms, was used because it offers details regarding the phenomenon studied, i.e., the green bullwhip effect on the supply chain. A single case can also properly represent the influence of primary stakeholders on a focal company in which there is a particular institutional environment. Pagell and $\mathrm{Wu}$ (2009) suggested studying more than one firm in a supply chain in order to obtain a better understanding of the sustainable supply chain concept across supply chains.

The case herein presented was selected based on criteria of atypical characteristics, because such characteristics are able to explain causes and consequences of a phenomenon studied (Flyvbjerg, 2006). The specific characteristics of this case are related to the institutional environment of the automotive battery sector (e.g high risk of environmental impact, and the sector has several regulations governing it), which is 
relevant for analyzing the role of a focal company in terms of leading supply chains toward more sustainable business practices in developing and emerging economies, such as Brazil (Silvestre, 2015).

\subsection{Case selection}

This study was conducted in the supply chain of an automotive battery sector in Brazil. The production and sale of batteries in Brazil focuses on the original equipment manufacturer (OEM) market - the auto manufacturers - and the spare part and exports markets, while the industry focuses on the production of lead acid batteries (Castro, Barros and Veiga, 2013).

Brazil is the eighth highest producer and the seventh highest seller of cars in the world (OICA, 2015). This country is also the leader in the production of motor vehicles (OICA, 2015) and the leader in the production and use of lead (ILA, 2016) in South America. The use of batteries is related to the production of cars, which means that studying companies located in Brazil is particularly relevant. Additionally, this country has particular characteristics in terms of the institutional environment of the automotive battery sector. Lead leakage from industrial residues in the country once contaminated one of its region's water tables and created health problems for part of the local population (Tomita, Padula, and Piccb, 2005). After the accident, a public environmental chamber was created that culminated in the State of Sao Paulo Environmental Company (CETESB) Board Decision No. 387/2010/P.

This sector was chosen because it is a more mature sector in relation to environmental management due to the environmental risk of its main input, lead acid (United Nations Environment Programme and United Nations Children's Fund, 1997). This sector has several regulations governing it. For example, there are two regulations for this sector in Brazil that are relevant. The first is from the National Environment Council (CONAMA), which has set down a resolution aiming to regulate the disposal and environmentally appropriate management of used batteries, particularly relating to their collection, reuse, recycling, and treatment or final disposal (CONAMA, 2010). The second is the National Solid Waste Policy (PNRS), which introduces guidelines relating to integrated management and to solid waste management (reverse logistics) (Presidency of the Federative Republic of Brazil 2010). However, the practice of reverse logistics in the sector occurs because the sector companies need to preserve the 
lead, its main raw material. The lead available for recycling in the sector and lead as a raw mineral are scarce (Chacón-Sanhueza and Fontanetti, 2006; Baenas et al., 2011).

The case in this study concerned one of the principal automotive battery manufacturers in Brazil (based on Castro, Barros, and Veiga (2013)) and its principal primary stakeholders. The companies that were elected as primary stakeholders are the main customer, the more collaborative supplier, and the main government body of the chosen automotive battery producer, which will be called Alpha Company.

Alpha is a Brazilian company with about 600 employees and is considered the fourth most important company in the sector in Brazil (Castro, Barros, and Veiga, 2013). Alpha operates in the OEM and in the spare parts and exports markets, and its principal customer is an auto manufacturer. The company has been certified according to ISO 9001 since 2000, ISO 14001 since 2006, and ISO TS 16949.

Alpha's main customer, which is a heavy vehicle manufacturer (front loaders, articulated trucks, and backhoes, among others), was chosen to represent the stakeholder customer. It is a multinational company with various production units spread around the world. The company exists in an environment with several stakeholders and types of pressure, including environmental pressure, especially from the international market. The company unit studied has 600 employees and is certified according to ISO 14001.

Alpha's main supplier of plastic components was chosen to represent the stakeholder supplier. This company is the third most important plastics manufacturer in the Brazilian automotive battery industry. It does not have any environmental certification, but it is certified according to ISO 9001 and ISO TS 16949.

The government body with the greatest action in the automotive battery sector and the body that Alpha considers to be the most important is CETESB. CETESB is responsible for controlling, inspecting, monitoring, and licensing pollution-generating activities (CETESB, 2015). It was chosen as the government stakeholder in this study.

\subsection{Data gathering}

Primary data were collected through interviews and direct observations conducted at the studied organizations, and secondary data were obtained from the organization's documents (reports, manuals, procedures, website information, etc.). Thus, primary and secondary data were triangulated (Yin 2010).

A case study protocol was developed for data collection based on the research question, which is: how do different institutional pressures exerted by different 
stakeholders tend to promote the green bullwhip effect by adoption of GSCM practices in a supply chain located in Brazil? Thus, constructs and variables were organized in the light of the theoretical background in order to prepare the script for the interview. Table 1 presents the constructs and variables of this research. The script for the interviews can be found at the appendix of the article.

\section{INSERT TABLE 1 HERE}

The green bullwhip effect was identified by examining the evolution of the adoption of GSCM practices across the supply chain as a result of environmental pressures from stakeholders. The circumstances of this evolution have been taken into consideration for an understanding of the spread of GSCM.

The script's structure was developed to be able to create categories of analysis of data and to guide the presentation of the case study results (Yin, 2010).

Focused interviews were conducted (Yin, 2010). The interviews followed a script with a given set of questions derived from the case study protocol. The interviews had a maximum duration of three hours. The interviewees at Alpha and at its three primary stakeholders occupied coordination positions or higher at their respective organizations (Table 2).

\section{INSERT TABLE 2 HERE}

The interviews were recorded, transcribed, and validated by the interviewees in a way similar to what Tomasin et al.'s (2013) method.

Direct observations were made in response to the interviews, and these observations focused on the organizations' main processes. For example, at Alpha's supplier, the production processes of the products supplied to Alpha were observed.

The secondary data were collected based on the interviews. Alpha's environmental manager provided the document: "Quality and Development Suppliers Manual." This manual provides guidelines for the assessment, monitoring, and development of Alpha's suppliers. The document is based on the specific requirements of Alpha's customers and the specific requirements of the automotive industry. The document presents, for example, topics that discuss the development of the supply chain 
and the evaluation processes of suppliers. This same document was also provided by Alpha's respondents' supplier. The Alpha customer interviewee provided the document "Supplier Evaluation Model." In this document are described all the supplier development processes, evaluations, and audits to which Alpha and other companies are subject. This document is based on legal aspects such as environmental legislation and customer requirements. The CETESB environmental engineer suggested reading the Board Decision Document No. 387/2010 / P (CETESB, 2010). This document is a regulation that regulates the premises and conditions for issuing installation, operation licenses, and monitoring in the automotive battery sector (CETESB, 2010).

\subsection{Data analysis}

The interviews were recorded, transcribed, and validated by the interviewees in way that imitated Tomasin et al.'s (2013) methodology. The text of the validated interviews was read and grouped into categories of analysis based on the constructs of the research: environmental pressures received/exerted from/on stakeholders, responses given to received environmental pressures, and GSCM practices adopted as a result of these pressures. Arguments from the text that could serve to fill each of the categories of analysis were highlighted and grouped together. The observations made were summarized in notes and these notes were read and grouped by categories of analysis. Likewise, the obtained documents were analyzed and the identified content was grouped into categories of analysis.

After this, narratives of the interviews were written and quotations were combined from key parts of the interviews. A table was elaborated for organizing the data. Additionally, the narratives were intertwined with theory to highlight the connection between empirical data and the previous theory in order to create new insights into the green bullwhip effect. These procedures were developed considering Eisenhardt and Graebner (2007).

\subsection{Reliability and validity in case research}

This research followed recommendations from Yin (2010) and from Voss, Tsikriktsis, and Frohlich (2002) in order to achieve rigor in the case study research.

For pursuing the construct validity, the scripts of the interviews were elaborated by considering the theoretical constructs and variables from the literature, which would allow for the establishing of a chain of evidence. Additionally, the interviewees 
validated the transcription of the interviews. The internal validity was achieved by collecting data from multiple sources (interview, direct observation, and secondary data) at each company studied. The external validity followed the replication logic in multiple case studies, which meant at the focal company and its primary stakeholders. Reliability was achieved using the same interview script for 4 companies so that the study could be repeated and to yield similar results. This meant that a single text could be analyzed.

\section{Results and Discussion}

\subsection{Results}

Table 3 shows the results that derive from the case study. In particular, it presents details of the type of institutional pressure in each relationship between stakeholders, the mechanisms used to exert environmental pressures, the reasons for the exerted pressures, and the GSCM practices adopted due to the institutional pressures present in each case.

\section{INSERT TABLE 3 HERE}

The environmental pressures received by Alpha's customer stakeholder have an impact on all the tiers of the studied chain.

Alpha's customer receives environmental pressures that influence it to adopt GSCM practices directly and indirectly. Eco-design is adopted because of demands for more environmentally efficient vehicles, as explained in an interview with the head of corporate values: quality, safety, and environment of Alpha's customer:

[...] We have special configurations depending on the market, which demand an additional criterion, an additional control. I'll give you an example: machines offered to the European Community. The European Community demands additional controls on noise emissions [...] So, depending on the market, if it is a regulated market in this aspect, they demand some additional controls. So, we handle all the control of air emissions, noise emissions, reports, which are delivered with the machine.

Part of the environmental pressure received by the customer is transferred to Alpha. For example, "audit," "demand for green products," and "contract" pressures, exerted by Alpha's customer, directly influence it to adopt internal environmental management practices, to cooperate with customers, and to make green purchasing decisions. They also indirectly influence it to implement reverse logistics practices. 
However, internal environmental management and reverse logistics are already earlier practices at Alpha. Internal environmental management has been practiced since Alpha's foundation in early 1990, as reported by Alpha's environmental manager:

Ever since we began here, there was an environmental management system, even though it was not certified. Ever since the company began in 1994, we have had an environmental management system.

At the time, the company hired former employees from one of its competitors. These employees brought with them knowledge of environmental aspects that related to the sector and implemented an internal environmental management system. On the other hand, Alpha has always practiced reverse logistics because the sector has a shortage of its main raw material, lead (Chacón-Sanhueza and Fontanetti, 2006; Baenas et al., 2011). However, its customers still exert an influence, even if indirectly, because this practice is demanded in the contract.

Alpha, in turn, transfers part of the pressure to its supplier. This pressure ends up directly influencing its supplier to adopt internal environmental management practices, green purchasing, and cooperation with customers.

CETESB does not directly influence the adoption of any practice, but Alpha considers it the most influential stakeholder when dealing with environmental issues. When Alpha's environmental manager was asked which one of the three stakeholders studied exerts environmental pressures with the greatest intensity on Alpha, he was emphatic:

The government. [...] I say government because of CETESB, which is very active. [...] it is the most active. That is also because of the experience with other environmental entities we know.

However, from the level of demands present in Board Decision No. 387/2010/P (CETESB, 2010), the existence of an environmental management system is understood as something that would help an organization to deal with all these demands. Thus, CETESB indirectly influences the adoption of Alpha's internal environmental management system.

CETESB also exerts environmental pressure on Alpha's customer and supplier, indirectly contributing to the adoption of the internal environmental management needed to deal with environmental controls and prevention.

In relation to the environmental pressures exerted by Alpha on its supplier, Alpha offers support for its demands to be met. This support is normally given through training, sharing and development of technologies, and cooperation between 
engineering departments at both companies, as reported by the commercial coordinator at Alpha's supplier:

[...] we have a monthly meeting [with Alpha], which encompasses quality and new developments; they inform how we can help them, what raw material they will use.

\subsection{Discussion}

The research data were collected and analyzed with the objective of understanding and analyzing how different institutional pressures promote the green bullwhip effect and the consequent adoption of GSCM practices across a supply chain. The principal analyses of this study are presented below, highlighting the study's contribution in terms of the elaboration of propositions. Figure 1 systematizes the propositions proposed in this study.

\section{INSERT THE FIGURE 1 HERE}

The types of environmental pressures received by Alpha's customer are a predominant factor when it comes to environmental pressures propagating along the supply chain. The customer receives environmental pressures through normative and coercive means (Hoejmose, Grosvold, and Millington, 2014), especially from international markets and customers (Table 3): regulations, audits, demand for green products, contracts with specific clauses, and embargoes. This is related to the fact that Alpha's customer is in a dynamic industry: vehicle manufacturing (Betts, Wiengarten, and Tadisina, 2015). As presented by Hoejmose, Grosvold, and Millington (2014), the demands of customers downstream in a supply chain may motivate a company to extend environmental practices upstream in the supply chain, and the contract between these companies may be subordinate to compliance with environmental requirements. In these cases, in which companies are responding to demands downstream in a supply chain, as presented by Hoejmose, Grosvold, and Millington (2014) and by Laari et al. (2016), the companies can simply transfer eventual environmental requirements to their suppliers using a coercive mechanism, thereby avoiding major investments in the implementation of cooperative GSCM practices. Alpha's customer does this, for example, when it demands that its suppliers has ISO 14001 certification; otherwise they cannot supply their products to the company. This would explain the customer's role in propagating environmental pressures in the studied supply chain, especially pressure on Alpha, and 
because the pressures exerted by Alpha's customer more effectively pressure Alpha into adopting GSCM practices than the environmental practices exerted by the government stakeholder, for example. It is thus possible to determine the first proposition of this study, proposition $1(\mathrm{P} 1)$.

P1: Environmental pressures are propagated across a supply chain, from tier to tier, and they can result in the adoption of GSCM practices.

The government stakeholder focuses on regulating the automotive battery sector through the coercive isomorphic process (Dimaggio and Powell, 1983). This is done by specific environmental demands, which are presented in Board Decision No. 387/2010/P (CETESB, 2010). Thus, the environmental pressures exerted by the government stakeholder on Alpha are meant to enforce these demands. Alpha meets these demands but without needing to adopt any GSCM practice directly. According to Meixell and Luoma (2015), in some cases, the government may influence sustainable practices, and in other cases may not. It is worth noting that the sector's institutional environment underwent great change after the accident that caused lead contamination in the State of São Paulo (Table 3), as described by Tomita, Padula, and Piccb (2005). This became evident from the reports of the interviews. The CETESB environmental engineer classified the accident as "a learning experience" and stated that "the episode promoted a standardization [...] a total change in the sector's behavior."

Thus, the fact that Alpha is in a high-risk sector in terms of health and the environment cannot be ignored when analyzing environmental pressures in the sector. According to González-Benito and González-Benito (2010), companies operating in sectors characterized by a high risk of environmental impact may receive greater environmental pressures than companies in other sectors. This also explains Alpha's perception that the government stakeholder exerts the strongest environmental pressure on it, since the government stakeholder, represented by CETESB, began to reinforce the sector's environmental regulations after the environmental accident involving the lead. These institutional pressures, as presented in the institutional theory, encourage Alpha to comply with CETESB demands to adopt elements of legitimacy — such as emissions controls and monitoring-and thus become isomorphic with its institutional environment (Hoejmose, Grosvold, and Millington, 2014; DiMaggio and Powell, 1983). This occurs in the same manner in the relationships between Alpha's customer and CETESB and between Alpha's supplier and CETESB. 
It is worth noting that the reason Alpha's customer pressures it to adopt prevention measures and compliance with current law is precisely because the sector is considered risky. This important role played by CETESB shows that regulatory entities are more important, in relation to environmental pressures, than customer and supplier stakeholders in sectors that present high risks to health and the environment. These facts may justify the government stakeholder's greater prominence compared to the customer and the supplier in terms of the perception of environmental pressures by Alpha. Based on this, proposition 2 (P2) is formulated as follows:

P2: The regulatory entities are more important, in relation to environmental pressures, than customer and supplier stakeholders in sectors that present high risks to health and the environment.

The environmental pressure mechanisms highlighted in the case study are similar to those presented by Björklund (2011), Chien and Shih (2007), Lee (2008), and Mohanty and Prakash (2014). Thus, regulations, audits, demand for green products, clauses in contracts, and embargoes are some of the mechanisms used by primary stakeholders to generate environmental pressures and to influence the adoption of GSCM practices, which determines proposition 3 (P3):

P3: Regulations, audits, demand for green products, clauses in contracts, and embargoes are some of the mechanisms used by primary stakeholders to generate environmental pressure and, in some cases, to influence the adoption of GSCM practices.

In the propagation of environmental pressures along the supply chain, a phenomenon called the green bullwhip effect has been identified. The term is used to describe a dynamic set of responses to environmental issues in supply chains, and the general result of this effect is that the environmental requirements of customers become more rigorous and restraining upstream of a supply chain (Lee et al., 2014). The green bullwhip effect can help explain the demands the customer makes on Alpha and the demands Alpha makes on its supplier. What is clear is that environmental pressures are propagated by the customer stakeholder in the supply chain, as described by Hoejmose, Grosvold, and Millington (2014) and by Laari et al. (2016). This stakeholder receives diverse coercive and normative pressures from its institutional environment. Another point that can be referred to this effect is the fact that the supplier adopted its first and only GSCM practices as a result of Alpha's environmental pressures. Thus, in a scenario with the green bullwhip effect, one can affirm that the more distant an 
organization is from the end customer in a supply chain, the greater the need will be to adopt GSCM practices to respond to this pressure. This is because Alpha's supplier is far from downstream in the supply chain and did not know precisely the demands of those tiers in the chain. When the environmental pressures reached it, in this case through Alpha, it had to respond with greater intensity because of the distortion of information concerning the chain's environmental demands. The environmental pressure arrives "late" and the organization has to act intensely, adopting initial GSCM practices such as internal environmental management, and more complex practices such as green purchasing and cooperation with customers. This determines proposition 4 (P4):

P4: The more distant an organization is from the end customer in a supply chain, the more delayed environmental pressures are when they arrive, which drive the organization to act intensely to respond to these environmental pressures, adopting initial and more basic GSCM practices, such as internal environmental management.

Lee et al. (2014), upon ascertaining the green bullwhip effect in their study, affirm that the rigor of environmental requirements tends to increase as they move upstream in a supply chain. In this study, environmental pressures do not tend to increase, but the necessary responses to meet the environmental pressures tend to be more intense. In other words, Alpha's supplier receives normative pressure to adopt GSCM practices, whereas Alpha and its customer receive normative and coercive pressures for the same purpose. However, since Alpha's supplier is far from Alpha's customer, it needs to adopt many more GSM practices to align itself with the customer's supply chain. Furthermore, it was observed that to compensate any difficulty for Alpha's supplier in responding to the environmental pressures exerted on it, Alpha cooperates with its supplier through shared environmental training, sharing and development of technologies, and cooperation, especially between the companies' engineering departments. This cooperation ensures Alpha will meet its customer's requirements and makes it easier for Alpha's supplier to meet the requirements Alphas' demands. Cooperation with stakeholders generates great benefits for organizations, as described by Chan et al. (2012), Matos and Hall (2007), and Vachon (2007). The direct involvement of customers in its suppliers' practices, as described by Lee (2008), drives the latter to participate more in GSCM initiatives. These measures, as discussed above, 
may also help to mediate the green bullwhip effect. Thus, proposition 5 (P5) is formulated as follows:

P5: Environmental pressures do not tend to increase along the supply chain, but tiers farther from the end customer tend to adopt many more GSCM practices. Cooperation between tiers is a means to mitigate difficulties in responding to environmental pressure.

It is noteworthy that the environmental pressure mechanisms adopted by Alpha are identical to those its customer uses on it. This may be explained by the normative isomorphism described in institutional theory. The latter is a mechanism used in the search for a standard to establish rules and standardize the institutional environment (DiMaggio and Powell, 1983).

The stakeholder that most strongly influences the adoption of GSCM practices is the customer. Lee (2008) considers the customer the principal channel of demand perception for "greener" products and services by organizations. It also considers that its direct involvement in supplier practices can drive its suppliers to participate more in GSCM initiatives. Lee (2008) supports the notion that the position in the chain is important for effective environmental pressures, as Lo (2013) also claims. It emerged from our case study and was supported by the literature that customers can be considered the most influential stakeholders for the adoption of GSCM practices. This direct involvement in supplier practices, as described by Lee (2008), can be seen in specific environmental pressures from Alpha's customer, which has induced Alpha to adopt some GSCM practices. This includes clauses in contracts that demand Alpha adopts an internal environmental management system that is ISO 14001 certified and reverse logistics practices. This determines proposition 6 (P6):

P6: Among the primary stakeholders, customers are the most influential in the adoption of GSCM practices.

Alpha exerts normative pressures on its supplier, making it adopt internal environmental management GSCM practices, cooperation with customers, and green purchasing, while Alpha's customer exerts a normative pressure on Alpha, leading it to cooperate with customers and adopt green purchasing practices. However, the coercive pressures exerted by Alpha's customer and by CETESB do not directly influence the adoption of GSCM practices. Based on this evidence, it is possible to affirm that in the context of an environmentally mature sector, such as the car battery sector, normative institutional pressures tend to be more effective for adopting GSCM practices than 
coercive ones. These differences in institutional pressures determine the green bullwhip effect and its effectiveness in relation to the adoption of GSCM practices. This means that there are such institutional pressures and that, consequently, stakeholders could increase the potential of the green bullwhip effect. Therefore, the final propositions, proposition 7 (P7) and proposition 8 (P8), are formulated as follows:

P7: in the context of an environmentally mature sector, normative institutional pressures tend to be more effective for adopting GSCM practices than coercive ones.

P8: differences in institutional pressures determine the green bullwhip effect and its effectiveness in relation to the adoption of GSCM practices.

Table 4 presents the arguments from the interviews and the secondary data that support the propositions mentioned. The Figure 2 presents the green bullwhip effect from the moment it begins at Alpha's customer to the point it reaches Alpha's supplier. All institutional pressures generated by primary stakeholders and the GSCM practices derived from them are indicated in the figure. The extension of the propagation of environmental pressure is highlighted by the supply chain in the figure.

\section{INSERT TABLE 4}

\section{INSERT THE FIGURE 2 HERE}

These evidences help to fill gaps in the literature, because few studies to date have tried to identify the circumstances that explain the levels of environmental pressure (Betts, Wiengarten, and Tadisina, 2015), as this study does in propositions P1, P2, P4, and P6. These propositions also help to explain the magnitude of the expansion and transfer of environmental requirements across a supply chain, thereby filling a gap in the literature pointed out by Larri et al. (2016). This study also demonstrates that different pressures have different effects when companies have the objective of developing environmental sustainability with the supplier. It thereby fills a gap in the literature pointed out by Sancha, Longoni, and Giménez (2015), as highlighted by propositions $\mathrm{P} 2$ and $\mathrm{P} 6$.

Lee et al. (2014) suggest that further studies are needed to examine the environmental demands imposed on stakeholders located downstream. This article explores this issue by analyzing different tiers in the same supply chain, as highlighted 
by proposition P4. Furthermore, Lee et al. (2014) highlight the need to investigate how institutional differences cause differences in the green bullwhip effect. By examining the institutional environment of a particular sector, the article offers insights (such as those presented in propositions P7 and P8) into the behavior of the green bullwhip effect in a chain that could present risks to the environment and to human health. Finally, it is noteworthy that in this study, environmental pressure does not tend to increase along the chain. Rather, the more distant the tier is from the end customer, the more it tends to adopt many more GSCM practices to respond to pressure, which corresponds with another point of view from the study by Lee et al. (2014).

Furthermore, few studies have examined stakeholder pressure in terms of managing sustainable supply chains in South America, as suggested by Meixell and Luoma's (2015) review of the literature. Therefore, this study contributes to an understanding of this issue in that region. In addition, by conducting this study in Brazil, the article generates knowledge about the dynamics of environmental issues in the country and contributes to an understanding of the differences in the dynamics between different countries (Laari et al. 2016; Silvestre, 2015; Lee et al., 2014).

\section{Conclusions}

This paper analyzed and explained how different institutional pressures created by different stakeholders tend to promote the green bullwhip effect and the consequent adoption of GSCM practices across a supply chain. Based on a case study, the relationship between a focal company in the automotive battery supply chain in Brazil and its primary stakeholders was analyzed and eight prepositions were proposed.

In summary, the main results from the article are: environmental pressures were found to propagate across a supply chain from tier to tier. The end customer receives the environmental pressure and initiates its diffusion along the supply chain. The tiers use several mechanisms of pressure such as regulations, audits, demand for green products, clauses in contracts, and embargoes. In this context, sector characteristics may make certain stakeholders more prominent than others. The adoption of GSCM practices may be influenced by primary stakeholders, the customer being the most influential. The position in a supply chain also plays an important role in intensifying the green bullwhip effect, because the farther an organization is from the end customer, 
the more delayed the environmental pressures will be. This leads the organization to act intensely to respond to environmental pressures, adopting the most complex GSCM practices. Cooperation between tiers is a means to mitigate the difficulties experienced by more distant tiers when it comes to responding to environmental pressure. In a context in which companies are immersed in a mature institutional environment, normative pressures are more effective than coercive ones, and these differences in institutional pressures shape the green bullwhip effect and its effectiveness in relation to the adoption of GSCM practices.

In terms of contributions, this article uncovered evidence, within the same study, of how different stakeholders exert different types of institutional pressure that influences the adoption of GSCM practices; analyzed institutional pressure from the viewpoint of the parties that create such pressure; and discussed the effects of the enlargement of environmental pressures along a supply chain in order to understand whether or not environmental pressures increase upstream supply chain

In opposition to the traditional bullwhip effect, the green bullwhip effect could have positive results in supply chains if focal companies provide shared environmental training and shared development of technologies to suppliers in order to reduce the enlargement of environmental pressures. Nevertheless, tiers that are far away from the customers in the supply chain should anticipate their actions and investments in order to develop environmental management practices capable of dealing with changes in the market context. Without competitiveness, which includes environmental initiatives, companies should put a lot of effort into responding to the green bullwhip effect.

Despite the study's contributions, it also presents limitations. First, as the study involved a specific supply chain in an emerging economy where a considerable number of environmental pressures existed, the obtained results might not be replicated in studies done on a different chain or a different sector. Second, the identification of the green bullwhip effect should involve more tiers in a chain, thereby characterizing and analyzing its effect on the adoption of GSCM practices with a broader range.

Finally, based on the results and the limitations of this study, the following future studies are proposed. First, the study should be replicated in relation to different chains. Second, it should be expanded to more tiers in a chain. Third, research should investigate how the green bullwhip affects the adoption of GSCM practices in relation to a bigger extension of a chain. This would involve analyzing the oscillations of 
institutional pressures exerted and received downstream to upstream and the best ways to handle the effect.

\section{Acknowledgments}

The authors would like to thank the National Council of Technological and Scientific

Development for supporting the research (130291/2014-5 and 304225/2013-4).

\section{References}

Aerts, W., Cormier, D., Magnan, M., 2006. Intra-Industry Imitation in Corporate Environmental Reporting: An International Perspective. Journal of Accounting and Public Policy, 25 (3), 299331.

Asgary, N., Li, G., 2014. Corporate Social Responsibility: Its Economic Impact and Link to the Bullwhip Effect. Journal of Business Ethics, 135 (4), 665-681.

Bai, C., Dhavale, D., Sarkis, J., 2016. Complex Investment Decisions Using Rough Set and Fuzzy cMeans: An Example of Investment in Green Supply Chains. European Journal of Operational Research, 248 (2), 507-521.

Ball, A., Craig., R., 2010. Using Neo-Institutionalism to Advance Social and Environmental Accounting. Critical Perspectives on Accounting, 21 (4): 283-293.

Berger, P. L., Luckmann, T., 1966. The Social Construction of Reality. Penguin Group, 249.

Betts, T. K., Wiengarten, F., Tadisina, S. K., 2015. Exploring the Impact of Stakeholder Pressure on Environmental Management Strategies at the Plant Level: What Does Industry Have to Do with It?. Journal of Cleaner Production, 92, 282-294.

Björklund, M., 2011. Influence from the Business Environment on Environmental Purchasing — Drivers and Hinders of Purchasing Green Transportation Services. Journal of Purchasing and Supply Management, 17 (1), 11-22.

Cai, S., Jun, M., Yang, Z., 2010. Implementing supply chain information integration in China: The role of institutional forces and trust. Journal of Operations Management, 28 (3), 257-268.

Carbone, V., Moatti, V., 2011. Towards Greener Supply Chains: An Institutional Perspective. International Journal of Logistics Research and Applications, 14 (3), 179-197.

Castro, B. H. R., Barros, D. C., Veiga, S. G., 2013. Baterias automotivas: panorama da indústria no Brasil, as novas tecnologias e como os veículos elétricos podem transformar o mercado global. BNDES Setorial, 37, 443-496.

CETESB (Companhia Ambiental Do Estado De São Paulo) 2010. "Board Decision No. 387/2010/P from December 2010” $\quad$ Acessed $\quad$ May $\quad 19 \quad 2015$. http://www.cetesb.sp.gov.br/userfiles/file/institucional/do/2010/DD_387_DO.pdf

CETESB (Companhia Ambiental Do Estado De São Paulo) 2015. “Institutional”. Acessed May 192015. http://www.cetesb.sp.gov.br/institucional/institucional/52-Hist $\% \mathrm{C} 3 \%$ B3rico

Chacón-Sanhueza, A. E., Fontanetti, A. R., 2006. Novos Processos de Reciclagem de Chumbo. Revista Matéria 11 (2), 146-154.

Chan, R. Y. K., He, H., Chan, H. K.., Wang, W. Y. C., 2012. Environmental Orientation and Corporate Performance: The Mediation Mechanism of Green Supply Chain Management and Moderating Effect of Competitive Intensity. Industrial Marketing Management, 41 (4), 621-630.

Chavez, R., Yu, W., Feng, M., Wiengarten, F., 2016. The Effect of Customer-Centric Green Supply Chain Management on Operational Performance and Customer Satisfaction. Business Strategy and the Environment, 25, 205-220.

Chien, M. K., Shih, L. H., 2007. An Empirical Study of the Implementation of Green Supply Chain Management Practices in the Electrical and Electronic Industry and Their Relation to Organizational Performances. International Journal of Environmental Science and Technology, 4 (3), 383-394.

Clarkson, M. E., 1995. A stakeholder framework for analyzing and evaluating corporate social performance. Academy of Management Review, 20(1), 92-117.

CONAMA (Conselho Nacional De Meio Ambiente) 2010. Resolução Nº 424, de 22 de abril de 2010. Acessed May 19 2015. http://www.mma.gov.br/port/conama/legiabre.cfm?codlegi=629. 
Dai, J., Montabon, F. L., Cantor, D. E., 2015. Reprint of: Linking rival and stakeholder pressure to green supply management: Mediating role of top management support. Transportation Research Part E: Logistics and Transportation Review, 74, 124-138.

Darnall, N., Jolley, G. J., Handfield, R., 2008. Environmental management systems and green supply chain management: complements for sustainability?. Business Strategy and the Environment, 17(1), 30-45.

DiMaggio, P. J., Powell, W. W., Powell, W. W., 1983. The iron cage revisited : institutional isomorphism and collective rationality in organizational fields. American Sociological Review, 48 (2), 147160.

Dubey, R., Gunasekaran, A., Childe, S. J., Papadopoulos, T., Wamba, S. F., Song, M., 2016. Towards a theory of sustainable consumption and production: Constructs and measurement. Resources, Conservation and Recycling, 106, 78-89.

Dubey, R., Gunasekaran, A., Ali, S. S., 2015. Exploring the Relationship between Leadership, Operational Practices, Institutional Pressures and Environmental Performance: A Framework for Green Supply Chain. International Journal of Production Economics, 160, 120-132.

Eisenhardt, K.. M., Graebner, M. E., 2007. Theory building from cases: Opportunities and challenges. Academy of Management Journal, 50, 25-32.

Fahimnia, B., Sarkis, J. Davarzani, H., 2015. Green Supply Chain Management: A Review and Bibliometric Analysis. International Journal of Production Economics 162, 101-114.

Flyvbjerg, B., 2006. Five misunderstandings about case-study research. Qualitative inquiry, 12(2), 219245.

Freeman, R. E., 1984. Strategic management: A Stakeholder Approach. Boston: Pitman.

Glaser, B. G., Strauss, A. L., 2009. The discovery of grounded theory: Strategies for qualitative research. Transaction Publishers.

Gonzáles-Benito, Javier; González-Benito, Óscar. 2006a. "A Review of Determinant Factors of Environmental Proactivity." Business Strategy and the Environment 102: 87-102.

Gonzáles-Benito, J., González-Benito, Ó., 2010. A Study of Determinant Factors of Stakeholder Environmental Pressure Perceived by Industrial Companies. Business Strategy and the Environment 181 (November), 164-181.

Gonzalez, P., Sarkis, J., Adenso-Diaz, B., 2008. Environmental management system certification and its influence on corporate practices: Evidence from the automotive industry. International Journal of Operations \& Production Management, 28(11), 1021-1041.

González-Benito, J., González-Benito, Ó., 2006b. The Role of Stakeholder Pressure and Managerial Values in the Implementation of Environmental Logistics Practices. International Journal of Production Research, 44 (7), 1353-1373.

Hazen, B. T., Cegielski, C., and Hanna, J. B., 2011. Diffusion of green supply chain management: Examining perceived quality of green reverse logistics. The International Journal of Logistics Management, 22(3), 373-389.

Hoejmose, S. U., Grosvold, J., Millington, A., 2014. The Effect of Institutional Pressure on Cooperative and Coercive 'green' Supply Chain Practices. Journal of Purchasing and Supply Management, 20(4), 215-224.

Hoejmose, S., Brammer. S., Millington, A., 2012. Green' Supply Chain Management: The Role of Trust and Top Management in B2B and B2C Markets. Industrial Marketing Management, 41 (4), 609620.

Hojas Baenas, J. M., Castro, R., Battistelle, R. A. G., Gobbo Junior, J. A., 2011. A Study of Reverse Logistics Flow Management in Vehicle Battery Industries in the Midwest of the State of São Paulo (Brazil). Journal of Cleaner Production, 19 (2-3), 168-172.

ILA (International Lead Association), 2016. "Lead Production \& Statistics" Accessed on the $5^{\text {th }}$ of May in 2016. http://www.ila-lead.org/lead-facts/lead-production--statistics

Jabbour, A. B. L. S., 2015. Understanding the Genesis of Green Supply Chain Management: Lessons from Leading Brazilian Companies. Journal of Cleaner Production, 87, 385-390.

Kauppi, K., 2013. Extending the use of institutional theory in operations and supply chain management research: Review and research suggestions. International Journal of Operations \& Production Management, 33(10), 1318-1345.

Ketchen, D. J., Hult G. T. M., 2007. Bridging organization theory and supply chain management: The case of best value supply chains. Journal of Operations Management, 25(2 ), 573-580.

Ketokivi, M., Choi. T., 2014. Renaissance of case research as a scientific method. Journal of Operations Management, 32(5), 232-240. 
Kilbourne, W. E., Beckmann, S. C., Thelen, E., 2002. The Role of the Dominant Social Paradigm in Environmental Attitudes: A Multinational Examination. Journal of Business Research, 55 (3), 193-204.

Khor, K. S., Udin, Z. M., Ramayah, T., and Hazen, B. T., 2016. Reverse logistics in Malaysia: The Contingent role of institutional pressure. International Journal of Production Economics, 175, 96-108.

Laari, S., Töyli, J., Solakivi, T., Ojala, L., 2016. Firm Performance and Customer-Driven Green Supply Chain Management. Journal of Cleaner Production, 112 (3), 1960-1970.

Lee, H. L., Padmanabhan, V., Whang, S., 1997. Information Distortion in a Supply Chain: The Bullwhip Effect. Management Science, 43 (4), 546-558.

Lee, S.-Y., 2008. Drivers for the Participation of Small and Medium-Sized Suppliers in Green Supply Chain Initiatives. Supply Chain Management, 13 (3), 185-198.

Lee, S. Y., Klassen, R. D., Furlan, A., Vinelli. A., 2014. The Green Bullwhip Effect: Transferring Environmental Requirements along a Supply Chain. International Journal of Production Economics, 156, 39-51.

Liou, J. J. H., Tamošaitienė, J., Zavadskas, E. K.., Tzeng, G., 2016, New Hybrid COPRAS-G MADM Model for Improving and Selecting Suppliers in Green Supply Chain Management. International Journal of Production Research, 54 (1), 114-134.

Lo, S. M., 2013. Effects of Supply Chain Position on the Motivation and Practices of Firms Going Green. International Journal of Operations \& Production Management, 34 (1), 93-114.

Matos, S., Hall, J., 2007. Integrating Sustainable Development in the Supply Chain: The Case of Life Cycle Assessment in Oil and Gas and Agricultural Biotechnology. Journal of Operations Management, 25 (6), 1083-1102.

Meixell, M. J., Luoma, P., 2015. Stakeholder Pressure in Sustainable Supply Chain Management: A Systematic Review. International Journal of Physical Distribution \& Logistics Management, 45 $(1 / 2), 69-89$.

Meyer, J. W., Rowan, B., 1977. Institutionalized Organizations : Formal Structure as Myth and Ceremony. American Journal of Sociology, 83 (2), 340-363.

Mohanty, R. P., Prakash, A., 2014. Green supply chain management practices in India: an empirical study. Production Planning \& Control, 25(16), 1322-1337.

OICA (Organisation Internationale des Constructeurs d'Automobiles) 2015. "Sale and production statistics" Acessed November 29 2015. http://www.oica.net/category/about-us/

Pagell, M., Wu, Z., 2009. Building a more complete theory of sustainable supply chain management using case studies of 10 exemplars. Journal of supply chain management, 45(2), 37-56.

Prajogo, D., Tang, A. K. Y., Lai,. K. H., 2012. Do Firms Get What They Want from ISO 14001 Adoption?: An Australian Perspective. Journal of Cleaner Production, 33, 117-126.

Presidency of the Federative Republic of Brazil.2010. “Law No. 12.305, August 2010”. Acessed May 19 2015. http://www.planalto.gov.br/ccivil 03/ ato2007-2010/2010/lei/112305.htm

Sancha, C., Longoni, A. C., Giménez, C., 2015. Sustainable Supplier Development Practices: Drivers and Enablers in a Global Context., Journal of Purchasing and Supply Management, 21 (2), 95-102.

Sarkis, J., Gonzalez-Torre, P., Adenso-Diaz, B., 2010. Stakeholder Pressure and the Adoption of Environmental Practices : The Mediating Effect of Training. Journal of Operations Management, 28 (2), 163-176.

Sarkis, J., Zhu, Q., Lai, K., 2011. An Organizational Theoretic Review of Green Supply Chain Management Literature. International Journal of Production Economics, 130 (1), 1-15.

Silvestre, B. S., 2015. Sustainable supply chain management in emerging economies: Environmental turbulence, institutional voids and sustainability trajectories. International Journal of Production Economics, 167, 156-169.

Srivastava, S. K., 2008. Network Design for Reverse Logistics. Omega 36 (4), 535-548.

Srivastava, S. K., 2007. Green Supply-Chain Management: A State-of-the-Art Literature Review. International Journal of Management Reviews, 9 (1), 53-80.

Tomasin, L., Pereira, G. M., Borchardt, M., Sellitto, M. A., 2013. How Can the Sales of Green Products in the Brazilian Supply Chain Be Increased?. Journal of Cleaner Production, 47 (May), 274-282.

Tomita, N. E., Padula, N. M. R., Piccb, G. E., 2005. Intoxicação por chumbo em crianças e o discurso da imprensa. Ciência \& Saúde Coletiva, 10, 111-119.

United Nations Environment Programme, and United Nations Children's Fund. 1997. “Childhood Lead Poisoning: Information for Advocacy and Action”. Acessed May 192015. http://www.unicef.org/wash/files/lead_en.pdf.

Vachon, S., 2007. Green Supply Chain Practices and the Selection of Environmental Technologies. International Journal of Production Research, 45 (18-19), 4357-4379. 
Voss, C., Tsikriktsis, N., Frohlich, M., 2002. Case research-case research in operations management. International Journal of Operations \& Production Management, 22 (2), 1995-219.

Wang, Y., Hazen, B. T., 2015. Consumer product knowledge and intention to purchase remanufactured products. International Journal of Production Economics, in press.

Wong, C. Y.; Wong, C. W. Y., Boon-It, S., 2015. Integrating Environmental Management into Supply Chains A Systematic Literature Review and Theoretical Framework. International Journal of Physical Distribution \& Logistics Management, 45 (1/2), 43-68.

Wu, H., Chang, S., 2015. A Case Study of Using DEMATEL Method to Identify Critical Factors in Green Supply Chain Management. Applied Mathematics and Computation, 256, 394-403.

Ye, F., Zhao, X., Prahinski, C., Li. Y., 2013. The Impact of Institutional Pressures, Top Managers' Posture and Reverse Logistics on Performance - Evidence from China. International Journal of Production Economics, 143 (1), 132-143.

Yin, R. K., 2010. Estudo de caso: Planejamento e Métodos. Porto Alegre: Bookman.

Zhu, Q, J., Sarkis., Lai, K., 2013. Institutional-Based Antecedents and Performance Outcomes of Internal and External Green Supply Chain Management Practices. Journal of Purchasing and Supply Management, 19, 106-117.

Zhu, Q., Geng, Y., Sarkis, J., 2016. Shifting Chinese organizational responses to evolving greening pressures. Ecological Economics, 121, 65-74.

Zhu, Q., Cordeiro, J., Sarkis J., 2012. International and Domestic Pressures and Responses of Chinese Firms to Greening. Ecological Economics, 83, 144-153.

Zhu, Q., Sarkis, J., Lai, K.., 2011. An Institutional Theoretic Investigation on the Links between Internationalization of Chinese Manufacturers and Their Environmental Supply Chain Management. Resources, Conservation and Recycling, 55 (6), 623-630.

Zhu, Q., Sarkis, J., Lai, K..., 2008a. Confirmation of a Measurement Model for Green Supply Chain Management Practices Implementation. International Journal of Production Economics, 111, 261-273.

Zhu, Q., Sarkis, J., Lai, K.., 2008b. Green Supply Chain Management Implications for 'closing the Loop'. Transportation Research Part E: Logistics and Transportation Review, 44 (1), 1-18.

Table $1-$ Constructs and variables of the research.

\begin{tabular}{|c|c|c|}
\hline \multicolumn{2}{|c|}{ Construct 1: Environmental pressures from stakeholders } & Variables \\
\hline $\begin{array}{l}\text { Environmental } \\
\text { pressures from } \\
\text { stakeholders }\end{array}$ & $\begin{array}{l}\text { Stakeholders exert environmental } \\
\text { pressures on organizations for } \\
\text { adopting GSCM practices } \\
\text { (Björklund 2011; Chien and Shih } \\
\text { 2007; Lee 2008; Mohanty and } \\
\text { Prakash 2013). }\end{array}$ & $\begin{array}{l}\text { The mechanisms used by stakeholders } \\
\text { to exert environmental pressures on } \\
\text { organizations include: } \\
\text { - Audits } \\
\text { - Regulations } \\
\text { - Demand for green products } \\
\text { - Competition } \\
\text { - Contracts with specific } \\
\text { - } \text { clauses } \\
\text { Embargoes }\end{array}$ \\
\hline \multicolumn{2}{|c|}{$\begin{array}{l}\text { Construct 2: Response from organizations to pressure } \\
\text { exerted by stakeholders }\end{array}$} & Variables \\
\hline $\begin{array}{l}\text { Response to pressure } \\
\text { exerted by } \\
\text { stakeholders }\end{array}$ & $\begin{array}{l}\text { Organizations tend to respond to } \\
\text { pressures exerted by stakeholders } \\
\text { through training and cooperation } \\
\text { with them, as well as the adoption of } \\
\text { environmental practices (González- } \\
\text { Benito and González-Benito 2006b; } \\
\text { Sarkis et al. 2010; Vachon 2007). }\end{array}$ & $\begin{array}{l}\text { Response to pressure exerted by } \\
\text { stakeholders: } \\
\text { - Environmental training } \\
\text { - Use and development of } \\
\text { technologies } \\
\text { - Cooperation with } \\
\text { stakeholders }\end{array}$ \\
\hline \multicolumn{2}{|c|}{$\begin{array}{l}\text { Construct 3: GSCM practices adopted in response to } \\
\text { environmental pressures from stakeholders }\end{array}$} & Variables \\
\hline $\begin{array}{l}\text { GSCM practices } \\
\text { adopted in response to } \\
\text { environmental } \\
\text { pressures from }\end{array}$ & $\begin{array}{l}\text { Stakeholders influence the adoption } \\
\text { of GSCM practices (Björklund 2011; } \\
\text { Chan et al. 2012; Chien and Shih } \\
\text { 2007; De Brito et al. 2008; }\end{array}$ & $\begin{array}{l}\text { GSCM practices: } \\
\qquad \quad \text { Internal environmental } \\
\text { management }\end{array}$ \\
\hline
\end{tabular}




\begin{tabular}{|c|c|c|}
\hline stakeholders & $\begin{array}{l}\text { Hoejmose et al. 2012; Lee 2008; } \\
\text { Matos and Hall 2007; Mohanty and } \\
\text { Prakash 2013; Sarkis et al. 2010; } \\
\text { Zhu et al. 2008). }\end{array}$ & $\begin{array}{ll} & \text { Green purchasing } \\
\text { - } & \text { Cooperation with customers } \\
\text { - } & \text { Investment recover } \\
\text { - } & \text { Eco-design } \\
\text { - } & \text { Reverse logistics }\end{array}$ \\
\hline \multicolumn{2}{|c|}{ Construct 4: Institutional pressures } & Variables \\
\hline $\begin{array}{l}\text { Institutional } \\
\text { pressures: isomorphic } \\
\text { processes }\end{array}$ & $\begin{array}{l}\text { Isomorphic processes are coercive, } \\
\text { mimetic, and normative (DiMaggio } \\
\text { and Powell 1983; Hoejmose, } \\
\text { Grosvold, and Millington 2014). }\end{array}$ & $\begin{array}{ll}\text { Institutional pressures: } \\
\text { - } & \text { Coercive isomorphic process } \\
\text { - } & \text { Mimetic isomorphic process } \\
\text { - } & \text { Normative isomorphic } \\
& \text { process }\end{array}$ \\
\hline
\end{tabular}

Table 2 - Interviewed organizations and position of the interviewees.

\begin{tabular}{c|c|c}
\hline Organization & Position of the interviewee & Interview duration \\
\hline Alpha & Environmental manager & 150 minutes \\
\hline Alpha's customer & $\begin{array}{c}\text { Head of corporate values: quality, } \\
\text { safety, and environment }\end{array}$ & 150 minutes \\
\hline Alpha's supplier & $\begin{array}{c}\text { Commercial coordinator } \\
\text { Environmental manager and } \\
\text { production coordinator }\end{array}$ & 180 minutes \\
\hline CETESB (government) & CETESB environmental engineer & 60 minutes \\
\hline
\end{tabular}

Table 3 - Type of institutional pressure in each relationship between stakeholders. 




\begin{tabular}{|c|c|c|c|c|}
\hline 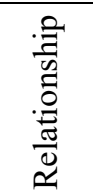 & $\begin{array}{l}\text { Environment } \\
\text { al pressures } \\
\text { (flow) }\end{array}$ & Environmental pressure mechanisms & Motivation for the exerted pressures & $\begin{array}{l}\text { GSCM practices } \\
\text { adopted }\end{array}$ \\
\hline 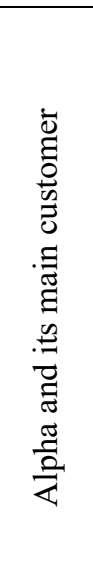 & $\begin{array}{c}\text { Customer } \\
\text { exerts } \\
\text { normative and } \\
\text { coercive } \\
\text { institutional } \\
\text { pressure on } \\
\text { Alpha. }\end{array}$ & $\begin{array}{c}\text { - Audit of product requirements, of the } \\
\text { environmental management system, of } \\
\text { the production process, and of } \\
\text { compliance with specific standards and } \\
\text { laws } \\
\text { - Contracts with specific clauses about } \\
\text { compliance with environmental } \\
\text { regulations, demand for an } \\
\text { environmental management system } \\
\text { certified by ISO 14001, and reverse } \\
\text { logistics practices } \\
\text { - Demand for green products: demand } \\
\text { for batteries with plastic boxes made of } \\
\text { plastic with environmental requirements }\end{array}$ & $\begin{array}{l}\text { - Batteries' components that can endanger human health and the } \\
\text { environment, such as lead } \\
\text { - Environmental pressures from the international market in which it operates } \\
\text { (regulations, audits, demand for green products, contracts, and embargoes) }\end{array}$ & $\begin{array}{l}\text { - Directly influenced by } \\
\text { the customer: } \\
\text { cooperation with } \\
\text { customers and green } \\
\text { purchasing } \\
\text { - Indirectly influenced by } \\
\text { the customer: internal } \\
\text { environmental } \\
\text { management and reverse } \\
\text { logistics }\end{array}$ \\
\hline 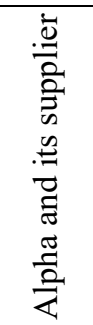 & $\begin{array}{l}\text { Alpha } \\
\text { exercises } \\
\text { normative } \\
\text { institutional } \\
\text { pressure on its } \\
\text { supplier. }\end{array}$ & $\begin{array}{c}\text { - Contracts that demand the supplier } \\
\text { have at least ISO } 9001 \text { (and will soon } \\
\text { demand ISO 14001) } \\
\text { - Audits based on ISO 9001 and ISO/TS } \\
16949 \\
\text { - Demand for green products (plastic } \\
\text { battery box with environmental } \\
\text { requirements) }\end{array}$ & - Demands from its main customer "share" the environmental pressure. & $\begin{array}{l}\text { - Directly influenced by } \\
\text { Alpha: internal } \\
\text { environmental } \\
\text { management, green } \\
\text { purchasing. and } \\
\text { cooperation with } \\
\text { customers }\end{array}$ \\
\hline
\end{tabular}




\begin{tabular}{|c|c|c|c|c|}
\hline 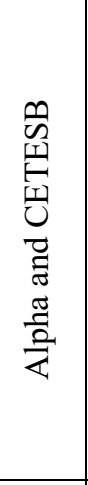 & $\begin{array}{l}\text { CETESB } \\
\text { exerts coercive } \\
\text { institutional } \\
\text { pressure on } \\
\text { Alpha. }\end{array}$ & $\begin{array}{l}\text { - Regulations: Board Decision No. } \\
\text { 387/2010/P, dated December 20, } 2010 \text {, } \\
\text { determines the premises and conditions } \\
\text { for issuing installation and operation } \\
\text { licenses, determining all care and } \\
\text { necessary monitoring in the automotive } \\
\text { battery sector in the State of São Paulo, } \\
\text { Brazil (CETESB 2010). } \\
\text { - Audits based on Board Decision No. } \\
\text { 387/2010/P } \\
\text { - Embargoes if Board Decision No. } \\
387 / 2010 / P \text { is violated }\end{array}$ & $\begin{array}{c}\text { - The automotive battery sector is a high-risk sector because of the lead } \\
\text { used. } \\
\text { - Sector history: A serious environmental accident occurred in the State of } \\
\text { São Paulo in } 2002 .\end{array}$ & $\begin{array}{l}\text { - Indirectly influenced by } \\
\text { CETESB: internal } \\
\text { environmental } \\
\text { management }\end{array}$ \\
\hline 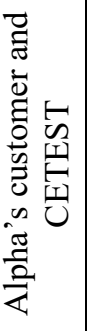 & $\begin{array}{l}\text { CETESB } \\
\text { exerts coercive } \\
\text { institutional } \\
\text { pressure on } \\
\text { Alpha's } \\
\text { customer. }\end{array}$ & $\begin{array}{l}\text { - Regulations: operation licenses } \\
\text { - Routine audits: inspection and audits } \\
\text { for issuance of licenses } \\
\text { - Embargoes if regulations are not met }\end{array}$ & $\begin{array}{l}\text { - Industry with potential risk for environmental impacts } \\
\text { - Standard inspection }\end{array}$ & $\begin{array}{l}\text { - Indirectly influenced } \\
\text { by CETESB: internal } \\
\text { environmental } \\
\text { management }\end{array}$ \\
\hline 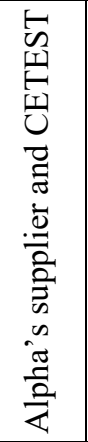 & $\begin{array}{l}\text { CETESB } \\
\text { exerts coercive } \\
\text { institutional } \\
\text { pressure on } \\
\text { Alpha's } \\
\text { supplier. }\end{array}$ & $\begin{array}{l}\text { Same as the relations between Alpha } \\
\text { and CETESB }\end{array}$ & - Be connected to the automotive battery sector, which is a high-risk sector & $\begin{array}{l}\text { - Indirectly influenced } \\
\text { by CETESB: internal } \\
\text { environmental } \\
\text { management }\end{array}$ \\
\hline
\end{tabular}

Table 4 - Arguments from interviews and secondary data that have supported the propositions proposed. 


\begin{tabular}{|c|c|c|}
\hline \multirow{2}{*}{ Propositions } & \multicolumn{2}{|l|}{ Supporting } \\
\hline & Quotations/Interviews & Secondary Data \\
\hline $\begin{array}{l}\text { P1: Environmental pressures are } \\
\text { propagated across a supply chain, } \\
\text { from tier to tier, and this can result } \\
\text { in the adoption of GSCM } \\
\text { practices. }\end{array}$ & $\begin{array}{l}\text { [Head of corporate values: quality, safety, and environment of Alpha's } \\
\text { customer speaking about environmental demands] "[...] We have special } \\
\text { configurations depending on the market, which demand an additional } \\
\text { criterion, an additional control. I'll give you an example: machines } \\
\text { offered to the European community [...]" [Speaking about noncompliance } \\
\text { with European market requirements] "You cannot supply it. It is a legal } \\
\text { requirement of that region." } \\
\text { [Alpha's supplier's commercial coordinator speaking about Alpha's } \\
\text { demands] "[...] we have a supplier manual we must follow to supply it. } \\
\text { So, the manal shows what we must do to be an Alpha supplier. [...] So, } \\
\text { this is all part of a quality score. And in this quality index, if my } \\
\text { performance is not good, I cannot supply Alpha. So, that's where the } \\
\text { pressure comes from, so I adjust my entire process to continue supplying } \\
\text { Alpha." }\end{array}$ & $\begin{array}{l}\text { - "Quality and development suppliers manual—from } \\
\text { - Alpha" } \\
\text { "Supplier Evaluation Model—from Alpha's } \\
\text { customer" }\end{array}$ \\
\hline $\begin{array}{l}\text { P2: The regulatory entities are } \\
\text { more important, in relation to } \\
\text { environmental pressures, than } \\
\text { customer and supplier stakeholders } \\
\text { in sectors with high risks to health } \\
\text { and the environment. }\end{array}$ & $\begin{array}{l}\text { [Alpha's environmental manager] "I say government because of } \\
\text { CETESB, which is very active }[\ldots . .] \text { it is the most active". } \\
\text { [Alpha's supplier's commercial coordinator speaking about } \\
\text { environmental pressures] "The greatest pressure, but then it becomes } \\
\text { standard, is a matter of you having [...] the environmental license } \\
\text { approved by CETESB." }\end{array}$ & - $\quad$ Board Decision No. 387/2010/P (CETESB 2010) \\
\hline $\begin{array}{l}\text { P3: Regulations, audits, demands } \\
\text { for green products, clauses in } \\
\text { contracts, and embargoes are some } \\
\text { of the mechanisms used by } \\
\text { primary stakeholders to generate } \\
\text { environmental pressure and, in } \\
\text { some cases, to influence the } \\
\text { adoption of GSCM practices. }\end{array}$ & $\begin{array}{l}\text { [Head of corporate values: quality, safety, and environment of Alpha's } \\
\text { customer speaking about environmental demands] "[...] We have special } \\
\text { configurations depending on the market, which demand an additional } \\
\text { criterion, an additional control. I'll give you an example: machines } \\
\text { offered to the European community [...]" [Speaking about noncompliance } \\
\text { with European market requirements] "You cannot supply it. It is a legal } \\
\text { requirement of that region [...]" [Talking about the development of } \\
\text { suppliers] "All our suppliers, without exception, have to go through } \\
\text { commercial contracts and technical approvals. So, every supplier has to } \\
\text { have rigorous technical development. There are a series of audits that are } \\
\text { done to validate their processes: the compliance to product requirements, } \\
\text { audits for the evaluation process, and audits evaluating legal compliance } \\
{[\ldots] \text {... }} \\
\text { [Alpha's environmental manager speaking about contract relations with } \\
\text { the customer]. "In the case [of the customer], it is an established, fixed } \\
\text { contract." } \\
\text { [Speaking of customer demands] "A battery that leaves the assembly line } \\
\text { must be white and of green material, milky and green material [...]." } \\
\text { [Speaking about the demand made by the customer for Alpha to have an }\end{array}$ & $\begin{array}{l}\text { - "Quality and development suppliers manual" } \\
\text { - "Supplier Evaluation Model—from Alpha's } \\
\text { customer" } \\
\text { - Board Decision No. 387/2010/P (CETESB 2010) }\end{array}$ \\
\hline
\end{tabular}


internal environmental system certified by ISO 14001] "One thing they demand is ISO 14001 environmental certification [...] [If the company does not have an internal environmental system certified by ISO 14001], there is no way to supply your customer [...]"

[Speaking about supplier audits] "There is a contract that demands audits in the supplier's processes. An auditor on behalf us go to the supplier's facilities."

[Alpha's supplier's commercial coordinator speaking about Alpha's demands] "[...] we have a supplier manual we must follow to supply it. So, the manual shows what we must do to be an Alpha supplier. [...] So, this is all part of a quality score. And in this quality index, if my performance is not good, I cannot supply Alpha. So, that's where the pressure comes from, so I adjust my entire process to continue supplying Alpha."

[Environmental

engineer

CETESB talking about the supervision of the automotive battery industry] "Our control is as follows We always check how the battery waste is handled in ordinary inspection sections because handling and storing have to follow our guidelines. We also check if companies are conforming to our regulation and if they have evidences to supply."

P4: The more distant an organization is from the end customer in a supply chain, the more delayed environmental pressures arrive and drive it to act intensely to respond to these environmental pressures, adopting initial and more basic GSCM practices, such as internal environmental management.

P5: Environmental pressures do not tend to increase along the supply chain, but tiers farther from the end customer tend to adopt many more GSCM practices. Cooperation between tiers is a means to mitigate difficulties in responding to environmental pressure.

P6: Among the primary stakeholders, customers are the
[Alpha's supplier's commercial coordinator about Alpha's demand for ISO 14001] "We do not have the ISO 14001 certificate, but we have been implementing it [...] We have been merely implementing the procedures that are needed."

[Alpha's supplier's environmental manager about the adoption of ISO 14001] "We have a (environmental) management system in the company, but it does not have the certification of ISO 14001. There is a project that in 2016 we will implement it. So, some of the practices that we have adopted are for facilitating the implementation of ISO 14001."

[Alpha's supplier's commercial coordinator about cooperation with Alpha] "[...] products produced for Alpha are 100\% developed with its cooperation $[\ldots]$ we have a monthly meeting that includes quality requirements [and also includes environmental requirements and] new developments, which means how we can support it in that, like which raw material will be used. We have developed some things [...] and we do not provide for others because it [Alpha] demanded exclusivity. [...] Customer cooperation practice is extremely implanted in our company. Well, we would not develop a product if there was no cooperation with the customer."

[Alpha's environmental manager about the requirement from its main customer that Alpha have ISO 14001] "One thing that our customer
- "Quality and development suppliers manual—from Alpha"

- “Supplier Evaluation Model_-from Alpha's customer"

- "Quality and development suppliers manual—from Alpha"

- “Supplier Evaluation Model—from Alpha's customer"

- "Quality and development suppliers manual" 


\begin{tabular}{|c|c|c|}
\hline $\begin{array}{l}\text { most influential for the adoption of } \\
\text { GSCM practices. }\end{array}$ & $\begin{array}{l}\text { demands is the environmental certification ISO } 14001 \text { [...] If we do not } \\
\text { have it, we can't provide for it [...]" } \\
\text { [Alpha's environmental manager about environmental requirements from } \\
\text { its main customer] "Batteries must be produced considering narrow } \\
\text { requirements from our main customer." } \\
\text { [Head of corporate values: quality, safety, and environment of Alpha's } \\
\text { customer about contract requirements for practicing reverse logistics] } \\
\text { "Each product has its prerequisites in the contract, such as reverse } \\
\text { logistics, packaging, emergency procedures, and licensing. [...] These are } \\
\text { required. It is contractual [that the battery suppliers (Alpha) must practice } \\
\text { reverse logistics]." }\end{array}$ & \\
\hline $\begin{array}{l}\text { P7: Normative institutional } \\
\text { pressures tend to be more effective } \\
\text { for adopting GSCM practices than } \\
\text { coercive ones, in a context of } \\
\text { environmentally mature sectors. }\end{array}$ & $\begin{array}{l}\text { [Alpha's environmental manager speaking about contract relations with } \\
\text { the customer] "In the case [of the customer], it is an established, fixed } \\
\text { contract." } \\
\text { [Speaking of customer demands] "A battery that leaves the assembly line } \\
\text { must be white and of green material, milky and green material [...]." } \\
\text { [Speaking about the demand made by the customer for Alpha to have an } \\
\text { internal environmental system certified by ISO 14001] "One thing they } \\
\text { demand is ISO } 14001 \text { environmental certification [...] [If the company } \\
\text { does not have an internal environmental system certified by ISO 14001], } \\
\text { there is no way to supply our customer [...]" }\end{array}$ & $\begin{array}{l}\text { - "Quality and development suppliers manual—from } \\
\text { - "Slpha" } \\
\text { "Supplier Evaluation Model_from Alpha's } \\
\text { customer" }\end{array}$ \\
\hline $\begin{array}{l}\text { P8: Differences in institutional } \\
\text { pressures affect the green bullwhip } \\
\text { effect and its effectiveness in } \\
\text { relation to the adoption of GSCM } \\
\text { practices. }\end{array}$ & & $\begin{array}{l}\text { - "Quality and development suppliers manual—from } \\
\text { - "Slpha" } \\
\text { "Supplier Evaluation Model_from Alpha's } \\
\text { customer" } \\
\text { - Board Decision No. 387/2010/P (CETESB 2010) }\end{array}$ \\
\hline
\end{tabular}




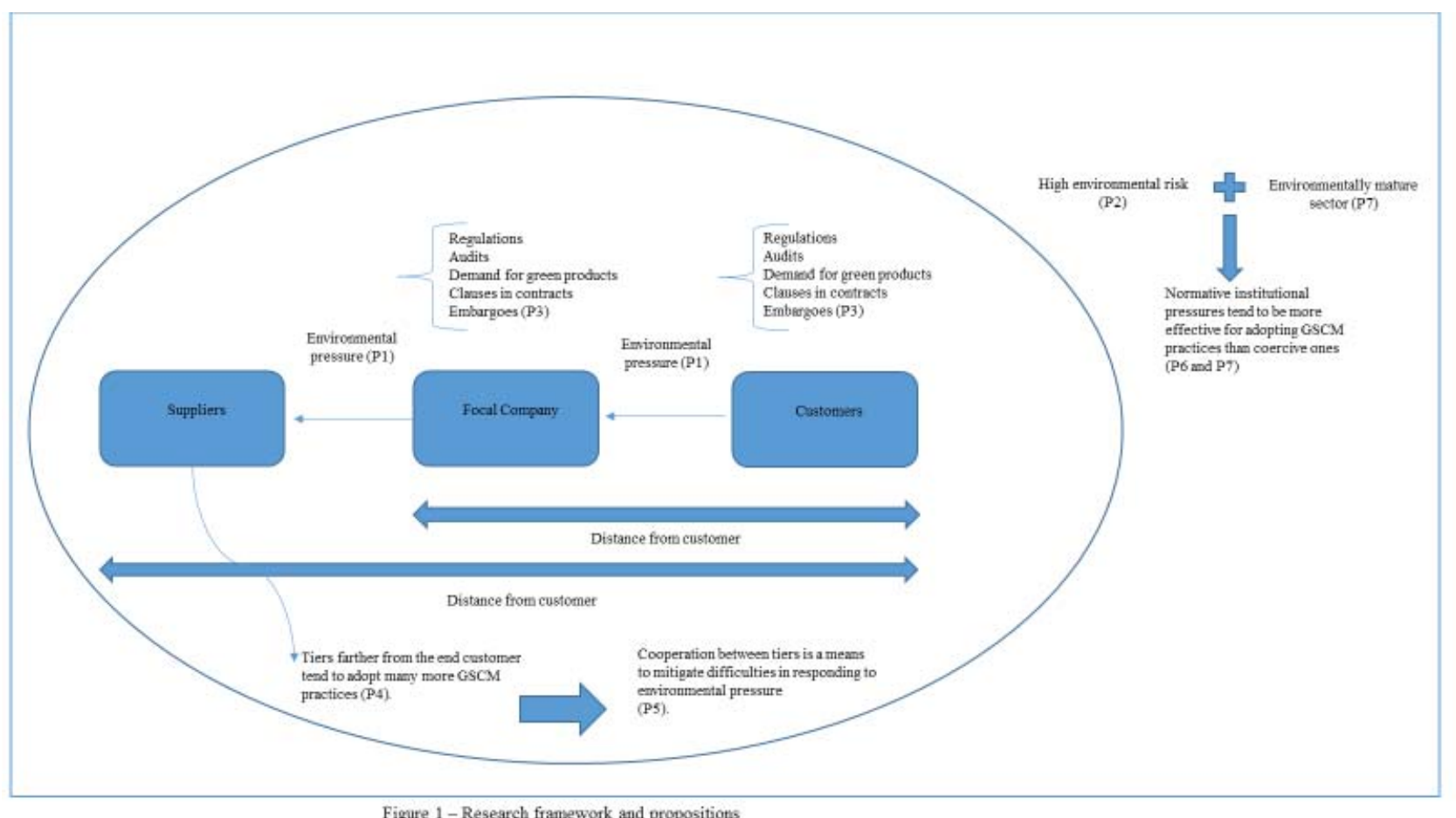

Figure 1 - Research framework and propositions 


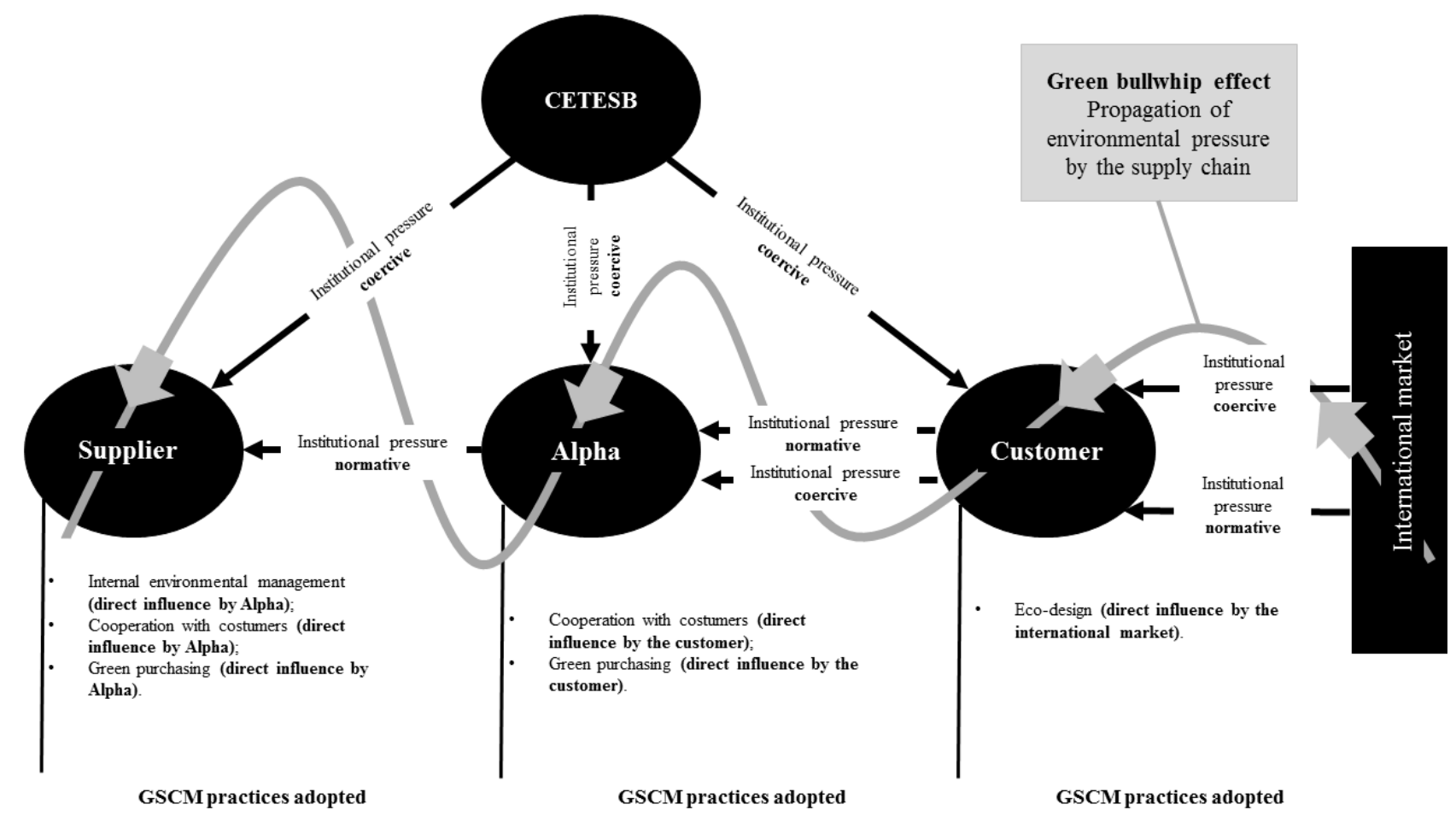


